\title{
Prevention partition for land subsidence induced by engineering dewatering in Shanghai
}

\author{
J. X. Wang ${ }^{1,2}$, X. T. Liu ${ }^{1}$, and T. L. Yang ${ }^{3}$ \\ ${ }^{1}$ Tongji University, Shanghai, China \\ ${ }^{2}$ CCCC Key Lab of Environment Protection \& Safety in Foundation Engineering of Transportation, \\ Guangzhou, China \\ ${ }^{3}$ Shanghai Institute of Geological Survey, Shanghai, China \\ Correspondence to: J. X. Wang (wang_jianxiu@163.com) \\ Published: 12 November 2015
}

\begin{abstract}
Land subsidence in shanghai has been found for more than 70 years. In the early years, it was mainly caused by groundwater exploitation. In recent years, engineering dewatering in shallow ground (within $90 \mathrm{~m}$ ) has become a major source for land subsidence in the rapid urbanization course. A management partition of land subsidence induced by foundation pit dewatering for the first confined aquifer was suggested.
\end{abstract}

\section{Introduction}

Shanghai is the economic and financial center of China. In 1939, land subsidence was first observed and its maximum value has reached $2.0 \mathrm{~m}$ until now. In the early years, the subsidence was caused by groundwater extraction for water supply. Later, the exploitation was restricted in order to control the land subsidence. However, during the rapid urbanization in recent years, lots of underground engineering were constructed, the engineering dewatering in shallow ground (within $90 \mathrm{~m}$ ) has become a major source contributing to increasing land subsidence.

Xu et al. (2009) analyzed the geohazards which may occur during the construction and maintenance of infrastructures in Shanghai, and the confined water was one of the main causes. Shen and $\mathrm{Xu}$ (2011) used numerical simulation to predict the behavior of land subsidence in Shanghai due to pumping of groundwater. Wang et al. (2012, 2013), Zhang et al. (2013), Luo et al. (2008) and Zhou et al. (2010) used numerical simulation to analyze the land subsidence caused by foundation pit dewatering. However, most previous studies focused on a single foundation pit. The land subsidence of engineering dewatering in a city's scale is not concerned too much.
Table 1. Stratigraphic characteristics of central city in Shanghai.

\begin{tabular}{lll}
\hline Layer No. & Composition & Note \\
\hline$(2)$ & Clay & \\
$(3)$ & Muddy clay & \\
$(4)$ & Muddy clay & \\
$(5)$ & Silty clay & \\
$(5)$ & Sandy silt & The micro-confined aquifer \\
$(5)$ & Silty clay & \\
$(6)$ & Clay & \\
$(7$ & Sand & The first confined aquifer \\
$(8$ & Clay & \\
(9) & Sand & The second confined aquifer \\
\hline
\end{tabular}

\section{Geological partition for strata combination}

The Quaternary sediments (Table 1) of Shanghai belong to the deposit of Yangtze River and tidal current of East China Sea. The foundation pit dewatering in Shanghai mainly relates to the first confined aquifer (layer (7)). The aquifer is formed in the Late Pleistocene and mainly consists of sand. In normal deposit environments, layer (6) is distributed above layer (7), but it is replaced by layers (5) 2 and (5) $3-4$ in the ancient river erosion area. Layer (8) is distributed between layers (7) and (9), but in some area, it does not exist where the layer (7) 


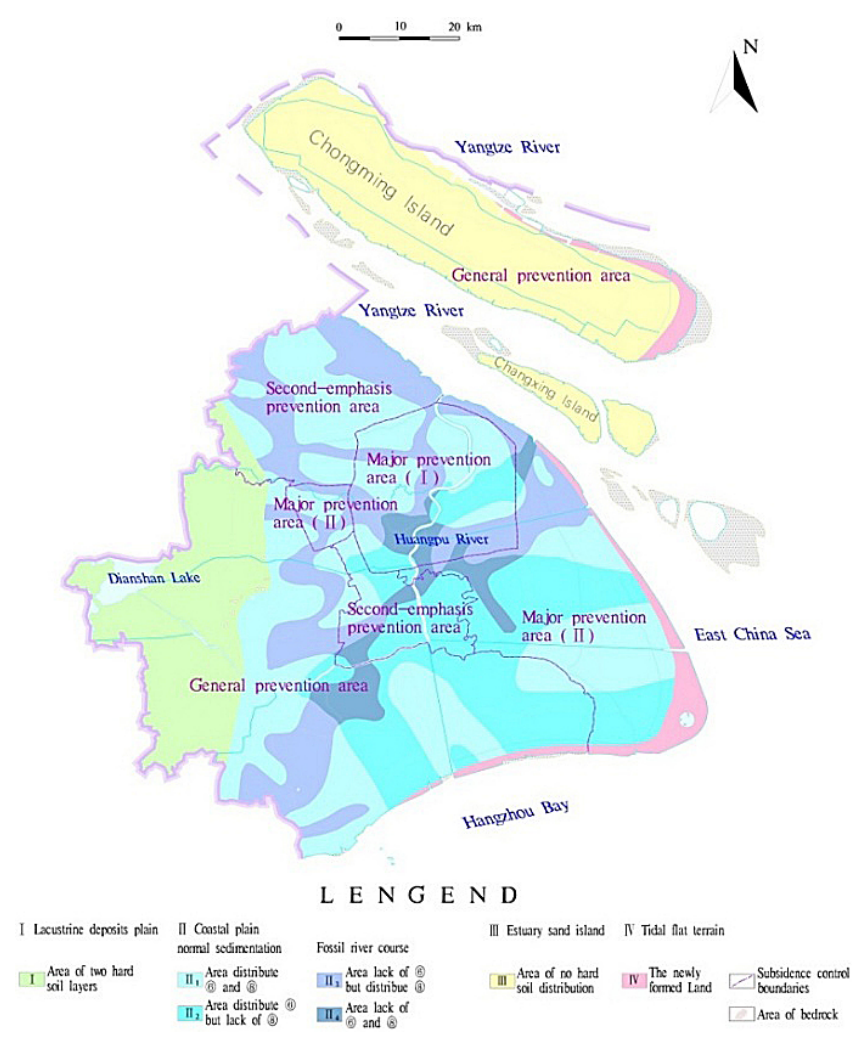

Figure 1. Geological partition for the first aquifer in Shanghai.

is connected with layer (9. So the first confined aquifer was divided into 7 geological partitions (Fig. 1 and Table 2).

\section{Prevention partition for land subsidence}

According to the urban development planning (SMCPA, 2012), the land subsidence prevention was divided into 4 partitions: emphasized prevention area I, emphasized prevention area II, second emphasized prevention area and general prevention area.

\section{Prevention partition for land subsidence induced by engineering dewatering}

In foundation pit dewatering, the curtain (diaphragm wall) is the most effective way to control the drawdown and land subsidence outside the pit (Wang et al., 2009). Considering the curtain's depth of present technology, the first confined aquifer was divided into 3 partitions in vertical direction. The dividing depth is 60 and $70 \mathrm{~m}$ separately.

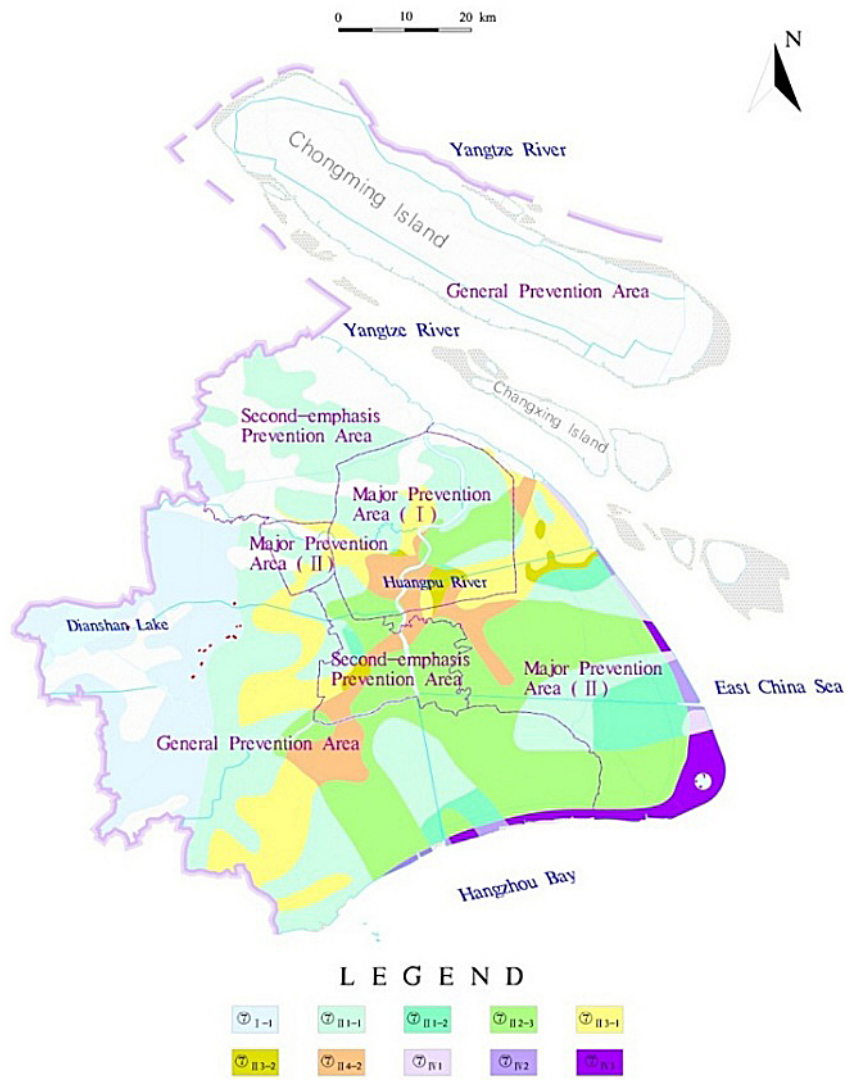

Figure 2. Prevention partition for land subsidence induced by engineering dewatering.

A prevention partition for land subsidence induced by engineering dewatering for the first confined aquifer was suggested (Fig. 2). It includes 11 sub-partitions (Table 3). The maximum drawdown for different foundation pits was suggested for each partition (Table 4).

\section{Conclusions}

Engineering dewatering has become a major factor of land subsidence in Shanghai. A prevention partition of land subsidence induced by engineering dewatering for the first confined aquifer was developed and suggested. 
Table 2. Geological partition for strata combination.

\begin{tabular}{|c|c|c|c|c|}
\hline \multicolumn{3}{|c|}{ Deposit environment } & \multirow[t]{2}{*}{ Characteristic } & \multirow[t]{2}{*}{ Composition } \\
\hline Partition & Sub-partition & & & \\
\hline $\begin{array}{l}\text { I } \\
\text { (Lacustrine deposits plain) }\end{array}$ & - & & Layers (6) and (8) & Silty sand \\
\hline II & Normal sedimentation & $\begin{array}{l}\mathrm{II}_{1} \\
\mathrm{II}_{2} \\
\end{array}$ & $\begin{array}{l}\text { Layers (6) and (8) } \\
\text { Layer (6), without Layer (8) }\end{array}$ & \multirow[t]{2}{*}{ Sand } \\
\hline (Coastal plain ) & Ancient river sedimentation & $\begin{array}{l}\mathrm{II}_{3} \\
\mathrm{II}_{4}\end{array}$ & $\begin{array}{l}\text { Layer (8), without layer (6) } \\
\text { without layers (6) and (8) }\end{array}$ & \\
\hline $\begin{array}{l}\text { III } \\
\text { (Estuary sand island) }\end{array}$ & - & & without layers (6) and (8) & Without \\
\hline $\begin{array}{l}\text { IV } \\
\text { (Tidal flat terrain) }\end{array}$ & - & & Newly formed land & Sand \\
\hline
\end{tabular}

Table 3. Prevention partition for land subsidence induced by engineering dewatering.

\begin{tabular}{|c|c|c|c|c|}
\hline \multicolumn{3}{|c|}{ Sedimentary characteristics and strata combination } & \multicolumn{2}{|c|}{ Bottom depth of the confined aquifer " $B$ " (m) } \\
\hline Partition & Sub-partition & Combination & Number & Depth (m) \\
\hline I & - & Layers (6) and (8) & 1 & $30<B \leq 60$ \\
\hline \multirow{4}{*}{ II } & $\mathrm{II}_{1}$ & Layers (6) and (8) & $\begin{array}{l}1 \\
2\end{array}$ & $\begin{array}{l}30<B \leq 60 \\
B>60\end{array}$ \\
\hline & $\mathrm{II}_{2}$ & Layer (6), without Layer (8) & 3 & (7) and (9) connected \\
\hline & $\mathrm{II}_{3}$ & Layer (8, without layer (6) & $\begin{array}{l}1 \\
2\end{array}$ & $\begin{array}{l}30<B \leq 60 \\
B>60\end{array}$ \\
\hline & $\mathrm{II}_{4}$ & Without layers (6) and (8) & 3 & (7) and (8) connected \\
\hline IV & - & Newly formed land & $\begin{array}{l}1 \\
2 \\
3\end{array}$ & $\begin{array}{l}30<B \leq 60 \\
B>60 \\
\text { (7) and (8) connected }\end{array}$ \\
\hline
\end{tabular}

Table 4. Control indexes of drawdown for partitions for land subsidence induced by engineering dewatering.

\begin{tabular}{lccc}
\hline \multirow{2}{*}{ Partition } & \multicolumn{3}{c}{ Prevention partition for land subsidence } \\
\cline { 2 - 4 } & Emphasized prevention partition (m) & Second-emphasized prevention (m) & General prevention partition (m) \\
\hline (7) II 1-1 & 2.0 & 2.0 & 2.0 \\
(7) II $1-2$ & 1.0 & 1.0 & 1.5 \\
(7) II $2-3$ & 1.5 & 2.0 & 2.0 \\
(7) II 3-1 & & & 1.5 \\
(7) II 3-2 & 0.5 & 1.0 & 1.5 \\
(7) II 4-3 & 1.0 & - & \\
(7) IV 2 & & & \\
\hline
\end{tabular}


Acknowledgements. This work is supported by the LSMP Open Funding (KLLSMP201403, KLLSMP201404), and the research grant (No. 201311045-04) from the Special Fund for Land and Resources-scientific Research in the Public Interest of China.

\section{References}

Luo, Z. J., Zhang, Y. Y., and Wu, Y. X.: Finite element numerical simulation of three-dimensional seepage control for deep foundation pit dewatering, J. Hydrodyn., 20, 596-602, 2008.

Shen, S. L. and Xu, Y. S.: Numerical evaluation of land subsidence induced by groundwater pumping in Shanghai, Can. Geotech., 48, 1378-1392, 2011.

SMCPA: The 12th Five-Year Plan for the land subsidence of Shanghai, SMCPA China, 2012.

Wang, J. X., Hu, L. S., Wu, L. G., Tang, Y. Q., Zhu, Y. F., and Yang, P.: Hydraulic Barrier Function of the Underground Continuous Concrete Wall in the Pit of Subway Station and its Optimization, Environ. Geol., 57, 47-453, 2009.
Wang, J. X., Feng, B., Liu, Y., Wu, L. G., Zhu, Y. F., Zhang, X. S., Tang, Y. Q., and Yang, P.: Controlling subsidence caused by de-watering in a deep foundation pit, B. Eng. Geol. Environ., 71, 545-555, 2012.

Wang, J. X., Feng, B., Yu, H. P., Guo, T. P., Yang, G. Y., and Tang, J. W.: Numerical study of dewatering in a large deep foundation pit, Environ. Earth. Sci., 69, 863-872, 2013.

Xu, Y. S., Shen, S. L., and Du, Y. J.: Geological and hydrogeological environment in Shanghai with geohazards to construction and maintenance of infrastructures, Eng. Geol., 109, 241-254, 2009.

Zhang, X. S., Wang, J. X., Wong, H., Leo, C. J., Liu, Q., Tang, Y. Q., Yan, X. L., Sun, W. H., Huang, Z. Q., and Hao, X. H.: Land subsidence caused by internal soil erosion owing to pumping confined aquifer groundwater during the deep foundation construction in Shanghai, Nat. Hazards., 69, 473-489, 2013.

Zhou, N. Q., Vermeer, P. A., Lou, R. X., Tang, Y. Q., and Jiang, S. M.: Numerical simulation of deep foundation pit dewatering and optimization of controlling land subsidence, Eng. Geol., 114, 251-260, 2010. 